\title{
ALEKSANDAR DEROKO: BETWEEN TRADITION AND MODERNITY
}

\author{
A B S T R A C T
}

Although numerous writings by professor Aleksandar Deroko raise essential questions about the nature, the history, and the methodology of architecture, he never provided a systematic theory, and his assertions did not belong to any mainstream architectural discourse. However, his romantic visions of remote, medieval monasteries and their origin on one hand, and on the other, the rational and methodical approach to heritage surveying evident in both his early texts and later architectural textbooks, resulted in some very novel theoretical ideas in architecture of the twentieth century. This paper examines the understanding of the tradition and modernity in the work of professor Deroko, investigates reasons behind his duality, explores the way he synthesised his research work with his pedagogical work, and tries to systematise his theoretical ideas.

\section{Renata Jadrešin Milić}

School of Architecture, Unitec Institute of Technology 
We headed back towards Raška. In a mail coach, we passed by the Church of St. Peter itself. My friend, a poet, has for the fifth time already sketched, on an envelope of some old letter, a glaringly white "chubby" little building, on its deepgreen hill above a bridge, delighted by the landscape of Novi Pazar. Cezanne's plans bring together tones from the warm cadmium coast of Dezeva to the coldest of blue of the distant mountains of Arnautluk. He [My friend] has been "haunted by the skeleton of Stupovi" whose silhouette "as a ghost crouches" up on the high hills, far above Dezeva. I still drink in the view until the first turn, from where it can no longer be seen.

A. Deroko, $1922^{1}$

\section{INTRODUCTION}

Professor Aleksandar Deroko's (1894-1988) wide-ranging interests in the field of architectural history included the protection and preservation of architectural heritage, as well as thorough examination and constant research of medieval Serbian (and the former Yugoslavian) architecture, and critical application of its principles to his own architectural practice. Still, none of these appears to enjoy significant attention within the realm of current architectural interest. Few scholars adopt Deroko's critical position and re-examination of the ideas of 'progress' compared with 'cultural continuity', the ideas of 'spirit' and 'inspiration', or 'good taste' in architecture, all of them considering the needs and psychology of the human being - the ordinary man - as a starting point for the work of an architect. However, what precisely constitutes Deroko's theory is not always easy to comprehend.

Although his numerous writings, starting from the third decade of the twentieth century, raise essential questions about the nature, the history, and the methodology of architecture, ${ }^{2}$ Deroko never provides a systematic theory or exposition. He rarely explicated his assertions through any particular or dominant theoretical approach. With his simple, personal and associative manner of writing and honest, but sometimes underdeveloped arguments, he was perhaps less an architectural writer than an architect who wrote. Nevertheless, he wrote one of the first textbooks about Serbian architectural history, and became the first to stress the importance of vernacular buildings often overlooked by architectural historians. His writing and conclusions were always based on first-hand observation. 
This paper aims to make two primary contributions to the existing body of work on professor Deroko. Firstly, it pays an honest tribute to Deroko himself and attempts to systematise the theoretical ideas of his written work in two fields: heritage protection and preservation, and architectural history; and secondly, it determines how progressive his approach to architecture and architectural history in the twentieth century was and remains so today.

The first part of the paper explores Deroko's relationship and life-long friendship with Rastko Petrović (1898-1949), a Serbian poet, writer, diplomat, literary and art critic. The content of Petrović's novels and poems reveal a deep and sincere artistic obsession with the romantic ideas of Slavic mythology. It is my belief that this is connected with Deroko's interest and passion for visiting inaccessible Serbian monasteries. Nonetheless, Deroko's romantic idea of reaching the remote walls of the past was at the same time combined with strong rationalism and realism in terms of heritage protection, with emphasis on surveying, conservation and preservation rather than restoration or ideal reconstruction of historical objects. In this, Deroko and Petrović appear to share similar contradictions. My aim is to show how their friendship influenced Deroko's theoretical ideas in architecture.

The second part of the paper examines how Deroko synthesised his research and his pedagogical work. Deroko wrote one of the first textbooks on the history of architecture in Serbia ${ }^{3}$ and here I investigate how he approached the topic and what criteria he used. I analyse his books and the methodology he applied and try to identify the theoretical principles that underpin them.

Finally, in the third part, I systematise the theoretical principles in which he believed as an architectural historian, architect-conservator, and as an architectdesigner. I hope that the reader will gain a coherent picture of the important connection which I believe exists between Deroko's romantic visions and his rational approach to heritage surveys and his writing on architectural history. My paper is the first to explore this relationship; in particular, I propose that there is no opposition, but rather integration of seemingly antagonistic, wellknown ideas of the twentieth-century architectural theory, revealed while reading "between" the lines of professor Deroko.

The material I use is already available in published form and predominantly includes Deroko's own written opus. Rather than aiming to provide new facts, I hope to possibly develop new understandings, believing that despite the availability of current sources, certain critical issues in Deroko's work often 
remain unnoticed, unaddressed and/or sometimes misunderstood. Thus, I can almost hear the voice of professor Deroko saying: 'If this paper serves as an orientation, support and help for further work, then it serves its purpose.'

ROMANTIC VISIONS VS. REJECTION OF IDEAL RECONSTRUCTION

Romantic Visions Seized between Tradition and Modernity

... obsessed with the magic of the old art...

Considering the historical circumstances in which he lived, Deroko's long life was eventful, exceptionally prolific, rich, and free. Born on September 4, 1894 in Belgrade, he spent almost his entire life in the Serbian and former Yugoslavian capital. Deroko grew up in an educated and cultured family, experiencing at an early age how his great-uncle Jovan Djordjević (1826-1900), a Serbian man of letters, the founder of the National Theatre in Belgrade and the Serbian National Theatre in Novi Sad. He compiled and prepared a Latin-Serbian dictionary and used to receive guests at times purely to practise his Latin. ${ }^{4}$ Deroko graduated in 1913 and enrolled at the Faculty of Technical Sciences (later the Faculty of Architecture, the University of Belgrade). Interrupting his schooling, as one of the 1,300 corporals he participated in the World War I and became one of the first Serbian war pilots.

Serbia. The 1920s were particularly important for his biography. This decade marked the beginning of Deroko's thirty-year long friendship with Rastko Petrović, a unique figure in Serbian literature and culture. Petrović became his great and faithful friend, interlocutor and companion who enriched Deroko's life above all others. Deroko continued his studies of architecture and art in Rome, Prague, Brno and Belgrade, graduating from University of Belgrade in 1926. He subsequently studied briefly on a French government grant in Paris, where he was taught by Gabriel Millet (1867-1953). Here, Petrović introduced him to a wide circle of renowned artists of the time.

Petrović (1898-1949), having survived the WWI, graduated from high school in Nice at the age of 17, and studied law in France. He is considered to be one of the most important and most progressive Serbian writers in the period between the two world wars. ${ }^{5}$

Petrović was intrigued by stories of origin, Slavdom, its mythology and the first sources of Serbian culture and art, and his first books clearly show this obsession. He was an author with a strong Dionysian sense of life, moving 


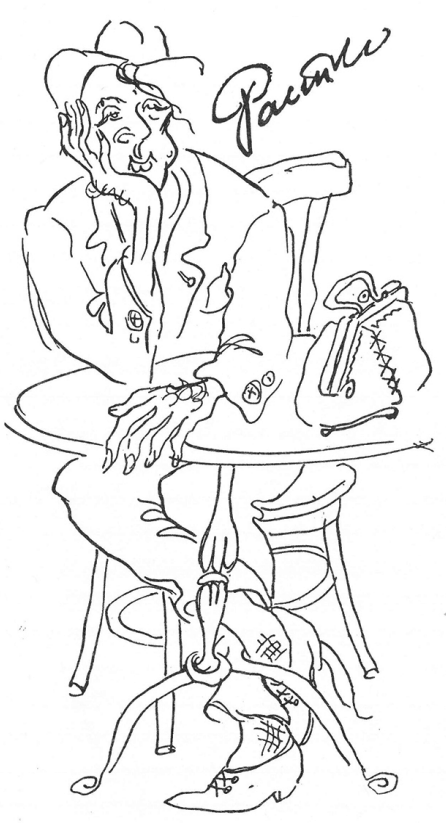

Fig. 1. Deroko's drawing of Rastko Petrović, "Eternal Traveler Rastko Petrović". (Source: Jovanović, Z. Aleksandar Deroko. Beograd: RZZZSK, 1991, 34.)

Fig. 3. Rastko Petrović drawing of Aleksandar Deroko, 1923. (Source: Jovanović, Z. Aleksandar Deroko. Beograd: RZZZSK, 1991, 39.)

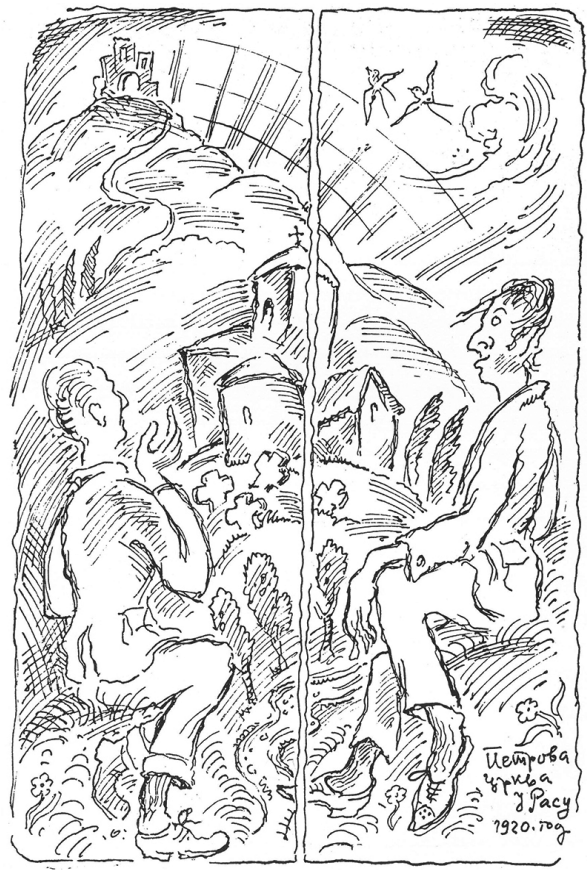

Fig. 2. Aleksandar Deroko and Rastko Petrović, 1920. The two friends drawing each other under the Petrova Church. (Source: Popović, R. Deroko i drugi o njemu. Beograd: Turistička stampa, 1984, 37.)

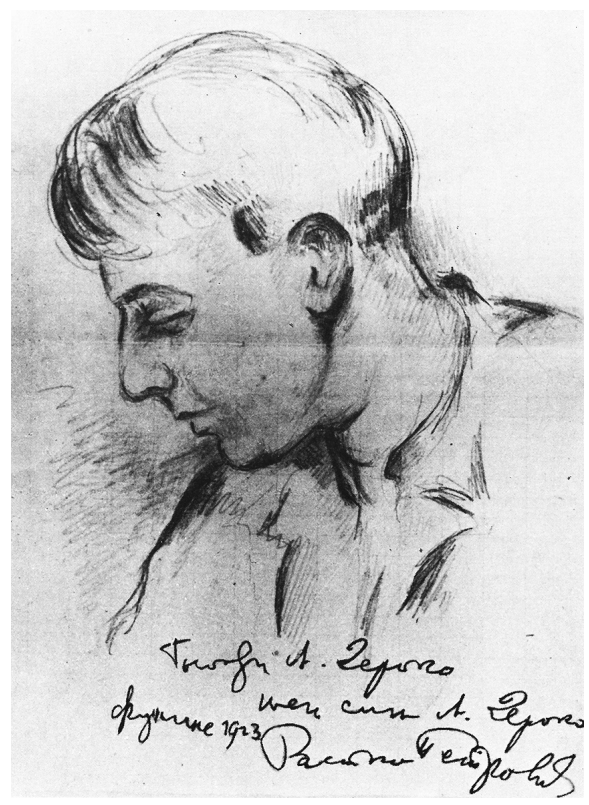


between extremes - from a cheerful, sensual dissolution of the Slavic pagan paradise in Burleska Gospodina Peruna Boga Groma (The Burlesque of Lord Perun, the God of Thunder) in 1921 to the dark atmosphere of destruction, violence and death in some poems in Otkrovenje (Revelation) in 1922. ${ }^{6}$ The Burlesque of Lord Perun, the God of Thunder is a novel often recognised as one of the most ambitious and unusual literary achievements in Serbian literature. ${ }^{7}$ In Slavic Pagan mythology Perun is the god of thunder, the highest god of the pantheon. Petrović's novel depicts the life of the old Slavic deities in a way that is full of eroticism, love, and free love, and includes numerous allegories, anachronisms, grotesque and absurd situations. The Burlesque embodies the avant-garde idea of mixing genres and literary types.

In the world of old Slavs - his permanent romantic preoccupation with Serbian folklore, medieval art and literature, Petrović sought sources of Serbian autochthonous poetic reconstruction. He introduced literary innovations and broke the unity of content, time and space-his narratives are 'unsettled', jumping from one topic to another. Having been exposed to new artistic aspirations in Paris, and under the strong influence of psychoanalysis, Petrović turned from conscious to unconscious aspects of human life. He developed a poetic theory of the disintegration of linguistic structures in order to provide purely sensual content; and he was the first among Serbian writers to become interested in exotic cultures. As a result, his quest for the synthesis between modernity and tradition, and the cosmopolitan and national spirit was novel, unexplored territory and extremely brave. Consequently, Petrović was misunderstood; being equally strange to proponents of the avant-garde and to conservatives, he was seen as incomplete, fragmented, and given to highs and lows. ${ }^{8}$ (Fig. 1)

Deroko and Petrović met in 1919. In his autobiography Deroko recalls the encounter fondly:

We met on his return to Belgrade, after World War I and Rastko's studies in Paris. He came from Paris thrilled by the legends of ancient Slavs ... and the vision of medieval Serbian art not only in terms of architecture and fresco painting, but also of the old literature, poetry, folklore epics ... as well as everything inherited, recorded and preserved to this day with stories, fairy tales, songs, costumes, jewellery. Rastko enthusiastically studied medieval Serbian art with professor Gabriel Millet in Paris ... and he was writing The Burlesque of Lord Perun at that time. I was in a similar mood then. I was also obsessed with the magic of that old art ... Soon the two of us would together eagerly see and experience it all close up. ${ }^{9}$ 
The two of them travelled together throughout Serbia, visited medieval cities, churches and monasteries, firmly bonded by their common admiration for Serbian medieval art (Fig. 2), which remained one of Deroko's prime interests throughout his professional life. They travelled 'for hours through the mountains and the waters', roaming the massifs of Serbia in search of hidden monasteries. The two would meticulously document every detail of the monuments of the past. However, their interest in these edifices went beyond archaeological fascination. Believing that it was the only way to "really experience", they would always spend the nights in a monastery, or behind the walls of an old fortification. ${ }^{10}$ Deroko and Petrović would sit in the darkness of these ancient buildings for hours, silent, immersed in an ecstatic experience of the past. Looking back at these years, Deroko notes that, at that time, the two truly believed that they did not create art, but only experienced ecstasy, asserting that it was the emotion that was important, not the art itself. ${ }^{11}$ The introspective contemplations of history influenced them both, leaving a specific mark on their creative work.

Medieval art and art in general came to bond Deroko and Petrović the most. They documented and drew everything regarding the monasteries, with Petrović copying complete wall frescoes. Deroko claims that Petrović used to bring full blocks of drawings and notes from each of his travels, which were later sent to Millet in Paris - precious to Millet because he had not seen half of these monasteries until his last two journeys to Serbia. ${ }^{12}$ Deroko notes that Petrović would survey building plans minutely, with measures for each façade and detail. The frescoes, icons and architecture also interested him. Although he was punctilious in recording entire Greek texts, his study never became dry or dull; it was always enlivened by real world observation and the excitement experienced 'as an artist in the midst of a museum of too rich art'. ${ }^{13}$ Deroko often describes Petrović drawing with whichever pens were at hand; a pencil and watercolour crayon occasionally and a small sketchbook were always somewhere close. ${ }^{14}$ (Fig. 3)

Paris. In the second half of the 1920s, Deroko and Petrović replaced their wanderings in the isolated wilderness of Serbia with the bustling streets of Paris. Graduating from the Architectural Department at the University of Belgrade, Deroko was awarded a French national scholarship. He arrived in Paris in 1926 to study under Gabriel Millet at the École des Hautes Études..$^{15}$ Petrović was already there to greet Deroko and introduce him to the very core of the Parisian avant-garde, discussing Surrealism, Dadaism, and other progressive concepts with Charles Despiau (1874-1946), Maurice de Vlaminck (1876-1958), Pablo 
Picasso (1881-1973), and Le Corbusier (1887-1965). ${ }^{16}$ Deroko established a personal friendship with Picasso, who gave him one of his coloured lithographs as a present (Fig. 4). ${ }^{17}$ Picasso and Deroko would also exchange letters after Deroko returned home to Belgrade, which reveals that they were more than mere acquaintances (Fig. 5).

Deroko wrote at length about his time with Petrović in Paris. The two would regularly visit Parisian museums, passionately and tirelessly. It was not with a desire to see everything, but only those pieces that would excite them, since "being excited" and discovering the artist's true intention was of the utmost importance to them. ${ }^{18}$ Recalling the memories of his dearest friend at that time, Deroko noted that while others in Paris were drawing a moustache on the Mona Lisa, Petrović preferred the great masters of the past. Although he had a deep appreciation of modern art, he preferred the paintings of Ingres. He was obviously devoted to the classic values of art, having no desire to experiment with the oddities that ruled over Fine Arts at that time. ${ }^{19}$ The same tendencies were visible in Deroko's work.

The inspiring life in Paris came to an end when Petrović had to return to Rome, and Deroko to school for "serious work". Deroko describes Millet's teaching method and his list of what was necessary for students to read at the National Library. Millet used to give his students tasks to prepare for presentations about monuments of medieval art in various distant parts of the world (predominantly the Middle East) that were still insufficiently studied, and to deliver lectures on the topics. Deroko comments on his own presentation and bad French, saying that 'using images was enough to understand each other - that was the main thing' ${ }^{20}$ The strength and importance of image in architecture and belief in the idea that the visual prevails over the verbal would mark Deroko as an architectural historian throughout his career.

Deroko continuously wrote about his friend, and his drawings found a place in Petrović's books. ${ }^{21}$ While Petrović's diplomatic service required the friendship to be conducted at a distance from the mid-1930s, his travels could have further influenced their exchange of opinions and attitudes. Although a coherent picture of the ideas that motivated them may still be open to debate, Deroko and Petrović both appear to exhibit contradictions: on the one hand, there are romantic visions about the origin; on the other hand, a very rational and methodical approach to carrying out surveys and measuring buildings, and an absence of attempts at romantic ideal reconstructions. 


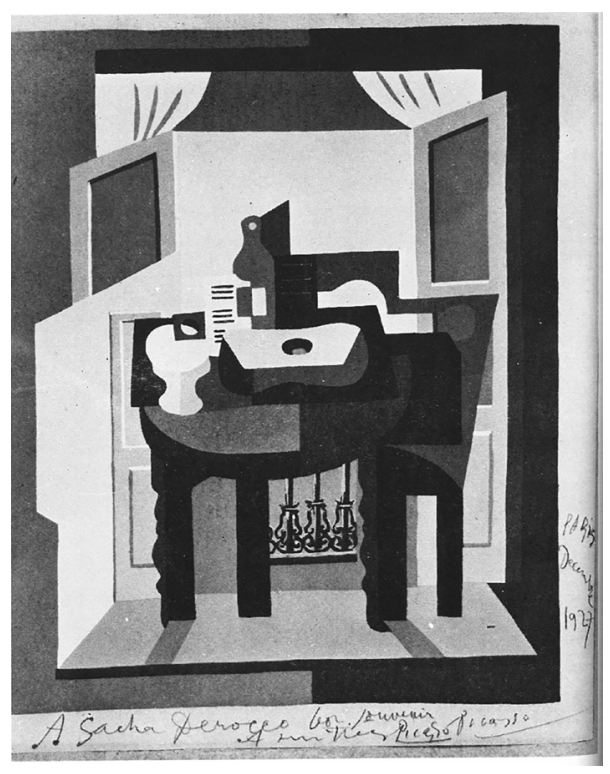

Fig. 4. Picasso's present for Deroko, lithography in color with dedication: "To Sasa Deroko, for memory and friendship, Picasso, Paris, December, 1923”. (Source: Popović, R. Deroko i drugi o njemu. Beograd: Turistička stampa, 1984, 40.)
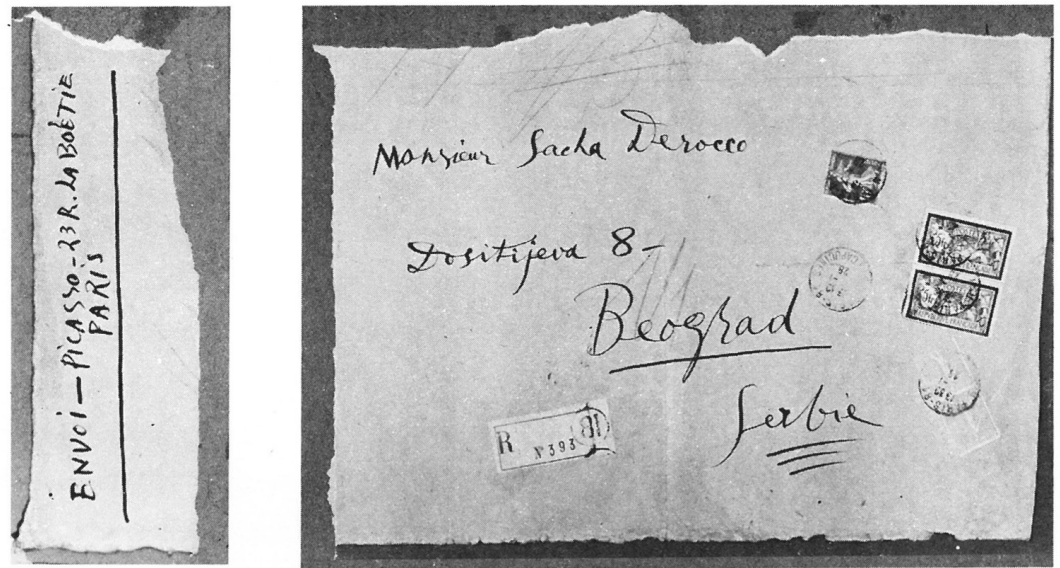

Fig. 5. Picasso's letter for Deroko. (Source: Popović, R. Deroko i drugi o njemu. Beograd: Turistička stampa, 1984, 41.) 
Rational Language in the Field of Architectural

Conservation and Preservation

... What does not exist anymore

should not be reconstructed again ...

On his return to Belgrade, Deroko started teaching the course Byzantine and Old Serbian architecture at the Faculty of Technical Sciences, and his academic journey to becoming a full-time professor began. He was an architectural historian directly involved in the conservation and preservation of architectural heritage. From the very beginning of his career, he completed numerous surveys, which he translated into the written word, continuously advocating and promoting heritage protection at international conferences and on committees. ${ }^{22}$ Sharing Petrović's obsession with the past, Deroko dedicated his life to heritage protection $^{23}$; contributed with his ideas to the development of theoretical methodological approach to heritage problems; raised important questions in the field of heritage preservation with regard to technical problems; ${ }^{24}$ and contributed much to the education of younger generations. All the time he was completely aware of his multiple roles as an architect, university professor and a member of committees. ${ }^{25} \mathrm{He}$ had an inner urge to raise the issue of protection of the remains of Serbian medieval culture and art and everything he wrote confirms that his relationship to heritage was deeply personal.

Deroko's writings about fieldwork show that he had studied the old monuments on his travels around the country 'mostly on foot or on mountain packsaddle horses, since there were very few real roads at that time'. The history of protection is not the subject of his writings, but rather personal memories from a time long before the existence of the Serbian institute for protection of monuments. Deroko recalls the practice at that time when confronted with challenging sites, surveys to be carried out with modest technology, without instruments, and in difficult conditions. The fieldwork experiences he describes convincingly and in such great detail, sharing practices in the field of protection that were "without any protection indeed", often carried enormous risks, and sometimes led to fatal outcomes. Sites which could only be reached in the saddle of a mountain pony, for hours over steep hills; with "no path, or even a small track leading to a monastery" were common in the field of protection in those days. ${ }^{26}$ On finally arriving at a site they would not have any equipment to conduct a survey. Deroko reports:

'We should have set the scaffold vault to protect the frescoes, and the dome, and me - up there on some rickety, makeshift scaffolding trying to catch centres to tailor the templates for the curves... and I wanted to photograph at the same time as well ... At times, I lost my balance and 
found myself gaping down at a chasm behind me. I was drenched in sweat and hardly managed to grab onto, I do not even know what, with those sweaty hands.' He further recalls: 'I didn't keep my head, but kept my camera instead. ${ }^{27}$

Although obviously carried out with very modest apparatus, Deroko affirms that it was solid work - 'primitive but solid', and writes respectfully of the old experts with many examples of such work. ${ }^{28}$ Experts in the field apparently did architecture, mosaics, fresco paintings, everything that was considered art and heritage.

Deroko would often criticise incompetence in dealing with heritage, which caused considerable damage. ${ }^{29} \mathrm{He}$ raises two groups of questions regarding the conservator's approach to old monuments. The first considers basic concepts and attitudes towards relocation of heritage remains. Although aware that with this issue he was raising one of the most troubling problems for museums internationally, Deroko was obviously against their removal, emphasising that his main interest was in pieces of architecture that were parts of complete monuments on the site, rather than in moveable objects, such as free-standing sculptures and paintings. ${ }^{30}$

The second group of questions is related to the basic approaches to the field of heritage, namely: is it better to carry out restoration or conservation? Deroko recalls examples of Viollet le Duc who "ruined Avignon", as well as the Greeks who did the same with the Church of Saint Demetrius in Thessaloniki after the Great Fire. On the other hand, the Stoa of Attalos in Athens, which was also completely reconstructed may be a good example, leading Deroko to conclude that there is no single answer to all questions for all cases. Considering the situation in Serbia, he promotes conservation and reiterates that the basic attitude in assessing and deciding what to do is much more important than the scale of damage; keeping authenticity is primary. ${ }^{31}$ When it comes to Serbian medieval cities, Deroko is convinced that it is wrong to attempt to reconstruct completely what was destroyed:

What does not exist anymore, even if it is known exactly what it looked like, should not be reconstructed again. It is best is to preserve what still exists and protect this from further deterioration. Those medieval cities that are further away from the village, whose walls and towers still hold, should be cleaned of debris and weeds; unsafe areas should be made safe, and driveways and paths should be made in order to make those cities accessible to all. ${ }^{32}$ 
Deroko's rational and methodological approach can also be detected in his advice that all necessary research and surveys should be done while doing preservation work, believing that ruins will certainly reveal other artefacts from the distant past. Deroko admits that there are always a number of doubts as to what extent something should be preserved as it was found, and what new should be added. However, his experience with 'old architecture on the ground' makes him certain about the importance of gaining 'better knowledge of the whole matter', revising 'the data by personal knowledge and remarks', and helping 'against fraudulent reconstruction', ${ }^{33}$ (Fig. 6)

\section{METHODOLOGICAL APPROACH TO ARCHITECTURAL HISTORY}

The way Deroko synthesised his research work with his pedagogical work is connected with his dual nature, both the romantic and the rational side of his personality. More than thirty years of tireless travels and research on architectural heritage enabled Deroko to become one of the founders of the history of architecture in Serbia as a modern scholarly discipline. The focus of his interest, research and publication was medieval architecture, and his work forks out in three directions: monumental architecture - churches and monasteries as the paradigm of the golden age of Serbian architecture, on one hand; cities and fortifications whose existence and characteristics he encountered during fieldwork on the other; and thirdly, vernacular architecture in which was his great interest and passion.

Deroko's best-known publication on Serbian monumental architecture is entitled Monumentalna i dekorativna arhitektura u srednjevekovnoj Srbiji (Monumental and Decorative Architecture in Medieval Serbia). ${ }^{34}$ Only three books on this topic had previously been written: L'ancien art Serbe by Gabriel Millet in 1919, Žiča i Lazarica by Miloje Vasić (1869-1956) in 1928, and Srednjovekovna umetnost u Srbiji i Makedoniji by Djurdje Bošković (19041990) in 1948. ${ }^{35}$ Deroko's book, first released in 1953, resulted from: 1) immediate surveys (started in the 1920s); 2) numerous research papers/studies that followed, and were published in daily newspapers, and reports; and 3) research of existing historical sources. The book was a university textbook and was mostly well received in professional circles. ${ }^{36}$ It was praised for showing a clear and precise methodology and Deroko's unique place in Serbian history, architecture and art. $^{37}$ 
Fig. 6. Deroko's drawing of Charles Diehl. In 1927 Deroko followed Diehl to visit Serbian medieval heritage; here Diehl is represented with nimbus and inscribed with Cyrillic alphabet, showing the respect Deroko had for him. (Source: Jovanović, Z. Aleksandar Deroko. Beograd: RZZZSK, 1991, 24.) About the visit of Charles Diehl see: Deroko, "Jedan članak o nama" Vreme, Beograd 8. V 1930; Deroko, A ondak je letijo jeroplan nad Beogradom, 200-207

Fig. 7. Deroko's drawings of "brvnara" from the mountainous regions of Raška. (Source: Deroko, A. Narodno neimarstvo I, Institut za narodnu umetnost Beogradskog Univerziteta, 1939.)
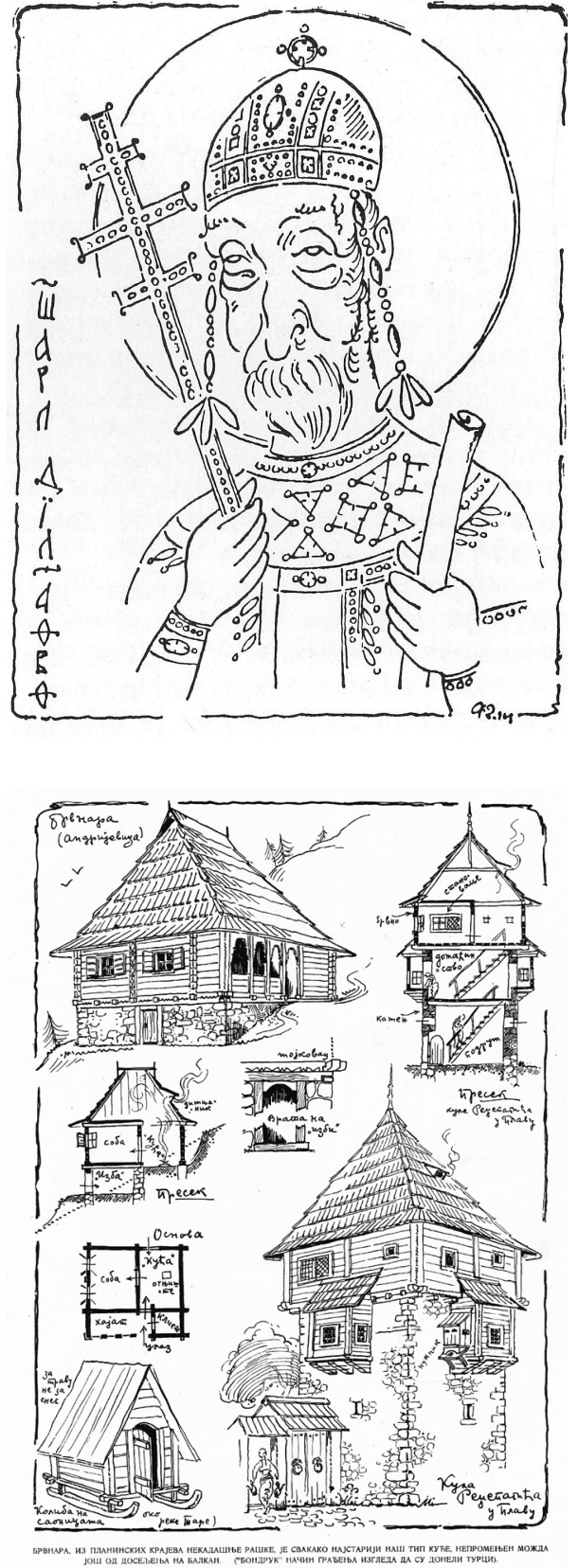
Secondly, Deroko's systematic study of Serbian medieval towns and fortifications resulted in Deroko's publications Srednjevekovni gradovi u Srbiji, Crnoj Gori $i$ Makedoniji (Medieval Towns in Serbia, Montenegro and Macedonia), ${ }^{38}$ Srednjevekovni gradovi u Srbiji (Medieval Towns in Serbia), ${ }^{39}$ Srednjevekovni gradovi na Dunavu (Medieval Towns on Danube). ${ }^{40} \mathrm{He}$ emphasizes that almost all the basic data were collected or checked during his fieldwork, especially for towns that had not previously been presented. ${ }^{41}$ Medieval towns in Serbia, Montenegro and Macedonia was a unique study of medieval fortified towns and the first to combine historical data and documents with illustrations.

Thirdly, Deroko's research on traditional vernacular architecture that seemed to be a pioneering venture, ${ }^{42}$ resulted in his books Folklorna arhitektura $u$ Jugoslaviji (Vernacular Architecture in Yugoslavia), ${ }^{43}$ and Narodno neimarstvo in two volumes: Stara seoska kuća ${ }^{44}$ (Vernacular Architecture I, Old Villagehouse) and Stara varoška kuća ${ }^{45}$ (Vernacular Architecture II, Old Town house). They were considered to be unique and the most complete studies on vernacular architecture in Serbia. ${ }^{46}$ Deroko began to reveal the value of Serbian vernacular architecture early in his research and fieldwork, while noticing and immediately drawing huts and houses with hearthstones, their details, bent protrusions, wooden door locks, as well as pieces of furniture and tools. His first two books and the only pre-war publications - Narodno neimarstvo I and II (Vernacular Architecture I and II), ${ }^{47}$ are actually collections of drawings in two volumes. Both publications comprise one sheet of text and 19 sheets of "drawings" with Deroko's hand-written notes on sepia paper, with pagination in red, which elevated them from mere books to exquisite items of art. Traditional architectural skills, the secrets of carpenters, types of chimneys, porches/ verandahs, windows, locks, and interiors, are depicted through the unique artistic means of Deroko's drawings. (Fig. 7)

Methodology

$$
\text { ... according to "one certain logic" ... }
$$

Deroko offers a comparative analysis of monumental architecture of "a certain period and character", aiming to establish a general overview that had not previously existed. ${ }^{48}$ Text and graphics are employed more or less equally for each monument. Plans of the monuments are given schematically and are mostly to the same scale to enable the dimensions of individual monuments to be compared. Deroko points out that this is the first attempt to present plans in such a way, which he considers essential for each comparative study (Fig. 8 ); the photos mainly show the general appearance of the monuments, while 
Fig. 8. Deroko's drawings - comparative study of plans of individual monuments. (Source: Deroko, A. Monumental and Decorative Architecture in Medieval Serbia, 248.)

Fig. 9. Plan of Golubac. (Source: Deroko, A. Srednjevekovni gradovi u Srbiji, Crnoj Gori i Makedoniji, 110 fig. 94)
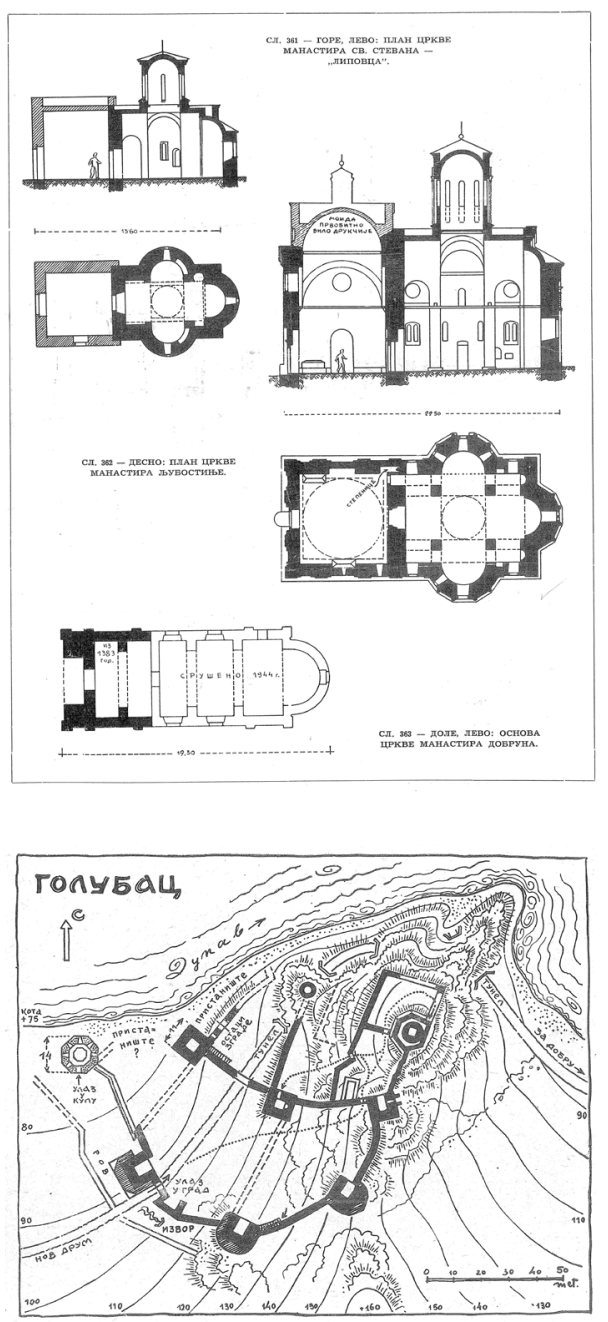

Fig. 10. Deroko's drawings, decorated sipovi na vratima i drvene kvake - archetypes

of functionality and aesthetics. (Source:

Deroko, A. Narodno neimarstvo I, Stara seoska kuća, Beograd: SANU, 1968. Fig 44.
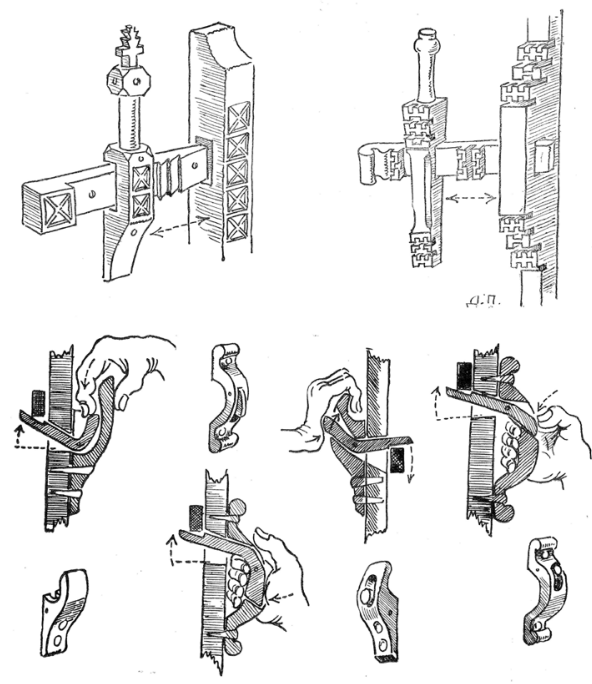
drawings explain stylistic features and details; maps provide guidance and comprehensive historical overview, a brief technical reminder at the end of the book defines the main technical terms used in the text, while summary and explanation of photos in both French and English languages enable foreign scholars to use the book. ${ }^{49}$ It seems very important for Deroko to use a clear and simple terminology and to highlight the point that presented architecture does not make a unified entity, but instead comprises different branches developed under the conditions and circumstances in specific areas and at a certain time.

Following Millet's work, Deroko adheres to the known architectural classification of medieval Serbia. It seems that he wanted to broaden Millet's existing systematisation of three "schools" (that he calls "groups"). At the very beginning of his book Deroko lists five, with an obvious need to discuss subtle differences and overlaps between them. ${ }^{50}$ However, he finally outlines the already known three - the School of Raška, the Serbo-Byzantine School, and the Morava School, as the most important and prominent. As an architectural historian, Deroko possesses clear awareness of the set methodology and the basic criteria, occasionally pointing out that whenever a certain stylistic group or specific building does not have distinguished architectural and stylistic unity, it will not be described in detail. He concentrates consistently on the overall balance of the study, where the main criteria are the architectural and stylistic significance of the building.

When moving to specific subsections dedicated to each "group", he explains the spatial and stylistic features of its buildings, following the sequence: spatial structure (typology according to floor plans), building materials, roofs, facades, interior decoration, and exterior decoration. In his conclusion of the Raška group, Deroko confirms that buildings' classifications were determined regardless of the time and place of their construction. This demonstrates that he was not interested in a chronological classification of architecture but rather in the basic architectural characteristics. ${ }^{51}$ Since his publication was made with respect to architectural rather than political development, and the second only helps to better understand the first one, Deroko testifies that he takes a look at all aspects of the area he is presenting in parallel, but always in relation to the relevant group. He presents only the most architecturally significant of these buildings, avoiding overloading the book with those that have only archaeological and historical significance. ${ }^{52}$ 
When Deroko writes about medieval towns and fortresses, his methodology of architectural history is somewhat different from that employed for monumental architecture. He brings a general overview of medieval towns, and it seems that he aims to provide an image of those monuments not only as archaeological sites but as living environments. His intention is primarily to give an inventory of the most important monuments in Serbia, Montenegro and Macedonia, with a brief description of them, architectural sketches or photographic images when possible, and finally to summarise the most important historical data. As in other books, Deroko sets out (and explains) a clear initial framework to which he adheres throughout his writings. ${ }^{53} \mathrm{He}$ also gives an explanation of terms, words and expressions important for the topic, with both ancient and modern meanings..$^{54}$

Deroko treats these towns primarily as monuments of architecture, while historical, military and other moments are included in order to complement the image of life in them. Deroko believes that medieval towns provided a more outstanding testimony to the cultural achievement and artistic ability of Serbian people than did medieval monastery buildings. ${ }^{55}$ The architectural form/shape of any part of any medieval city depends on the particular conditions that had to be met. ${ }^{56}$ Therefore they represent a kind of document and source that help to reconstruct certain moments in the history, economics, social relations and lifestyles of Serbian ancestors. ${ }^{57}$ (Fig. 9).

In his third group of books, Deroko wanted to comprehend the vernacular architecture of the villages and the townhouses in Serbia, again mainly from the architectural point of view. ${ }^{58}$ An ethnographic study and display of national life and houses, a sociological study, various mutual relations and how these develop, and "inner life" of those buildings, were only a background for Deroko - a basis from which spatial development starts. ${ }^{59}$ The main objective of his textbooks is to attempt to present a brief systematic overview of the principal and most characteristic 'shapes and appearance' of residential houses in the villages and towns in all corners of the former Yugoslavia. So, Deroko's categorisation of vernacular architecture arises out of the building functions primarily - their programme, form/shape, style, and construction materials. In doing so, he pays particular attention to the skill of building and expression of aesthetic aspirations. Deroko underlines that the shapes and appearance of architecture developed and evolved over the centuries (from both the distant and recent past) always and inevitably, spontaneously and sincerely, as a reflection of the needs, purpose, function, and a rational use of building materials - and without any particular ambition for a fashionable or useless embellishment. 
In doing so, affection and a sensibility for what is expressive helped in the construction of distinct and harmonious entities, while decoration was tastefully limited only to certain parts of these entities, even for household items. Deroko gives attention primarily to these architectural values, especially considering that such architecture is rapidly disappearing. ${ }^{60}$ His immensely broad approach to vernacular buildings made him be interested not only in houses, but in everything else "subordinate" to them as well, from outbuildings of lower value, tools and other items of daily use, to the decorations in which a builder's approach similar to modern artistic abstraction could often be seen (Fig. 10).

Deroko relies primarily on the material that still existed and could be observed, albeit no longer intact in the sites he would explore. ${ }^{61}$ Existing sources on the topic of vernacular architecture, including many old travel books abundant with data, he used only for the parts he considered relevant to building skills, careful not to lose the main idea with excessive details or "exceptions to the rule". His goal was more to make an attempt at synthesis than to enumerate all possible examples, data and phenomena as he did with medieval towns ('settlements'), ${ }^{62}$ underlining his distinct approach in accordance with the material he had available.

Deroko researched global architectural history as well, published in his book Arhitektura starog veka (Architecture of Old Century). ${ }^{63}$ This historical overview is again filled with drawings, illustrations, and theoretical positions resulting from the knowledge he obtained fom fieldwork and from personal study of existing material. ${ }^{64}$

Deroko's methodological approach is again obvious from the very beginning: he presents more general overviews, examples of monuments themselves with their details and stylistic characteristics, and places less emphasis on overdetailed historical data (places, dates, and figures). He insisted on presenting the architectural activity of certain ethnic groups and certain historical periods that could be "architecturally" classified into distinct units. He identified/ recorded the important material and social moments; circumstances resulting in the appearance and development of architectural activities; and the mutual influences and connections between civilizations. However, it is obvious that in Deroko's approach to architectural history, exclusive division by chronology was subordinated to the division by "one certain logic". Deroko believed in a chronological approach to architectural history only as a general framework. ${ }^{65}$ He explained that he didn't take one and the same rigid system for civilizations - the strict chronology of the monumentsor the character of buildings and 


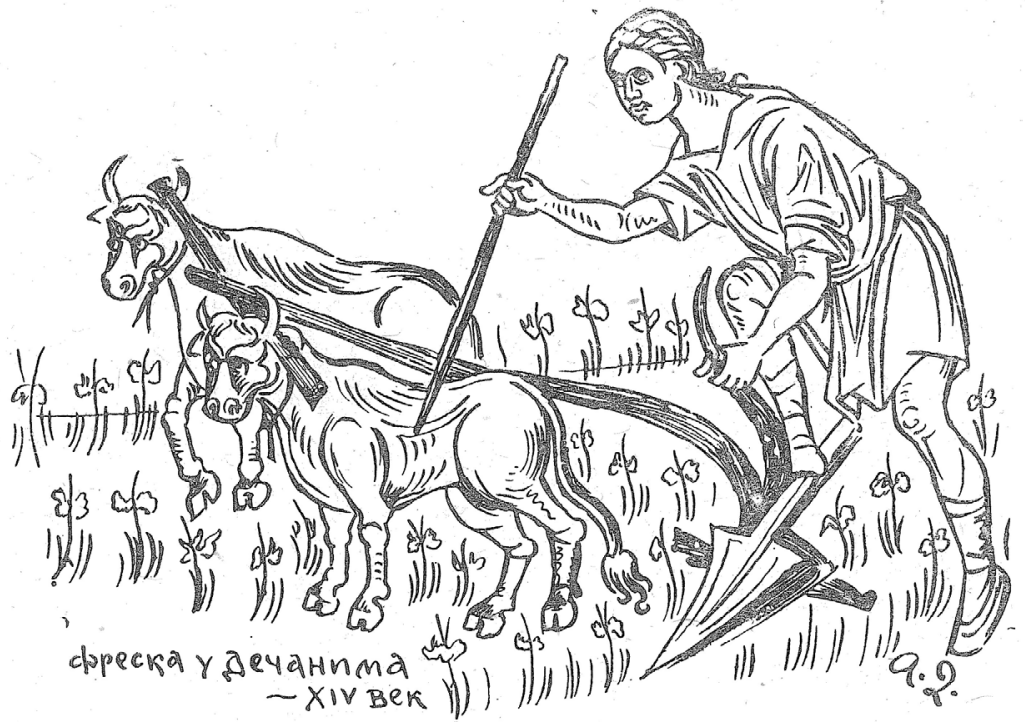

Fig. 11. Deroko's drawing of life in medieval towns, scenes representing ploughing. (Source: Deroko, A. Srednjevekovni gradovi u Srbiji, Crnoj Gori i Makedoniji, 11, fig. 1)

Fig. 12. Deroko's drawing of King Dragutin, according to authentic portrait from old fresco. (Source: Deroko, A. Srednjevekovni gradovi u Srbiji, Crnoj Gori i Makedoniji, 114, fig. 99) 
construction methods. The first way would be largely historical, Deroko says, while classification by the character of buildings would be disadvantageous to the extent that civilizations often constructed buildings of different character/ type, giving examples of palaces in Babylon and Assyria, tombs and temples in Egypt, and temples in Greece. His approach was rather "according to one certain logic" - and it always sought to point out everything that was most important from the architectural point of view for a particular civilization he presented.

Text vs. Image

$$
\text { ... to evoke a complete picture of reality ... }
$$

Perhaps partly coming from his early Parisian and medieval Serbian experiences with Petrović, or as a result of his dual nature - both romantic and rational, Deroko believed that architectural book illustrations have the same value as textual explanations. His books are suffused with plans, photos, façade drawings, portals, windows, and other architectural elements. His drawings are recognisable, abundant with details, and 'designed to facilitate access to the complex contents for the readers ${ }^{96}$ As a result, apart from providing arguably the most complete history of Serbian medieval architecture to date, Deroko's publications possess unquestionable artistic value.

In the books devoted to medieval towns and fortifications, his drawings of town life depict scenes representing medieval people, warriors in battle, shepherds and peasants ploughing, playing and dancing, almost as if seen by a medieval painter of miniatures or marble carver in the suburbs of such towns. They are included to balance technical content and evoke a complete picture of reality at that time (Fig. 11). At times, sketches of people who owned the towns or were fighting for them were also included, according to authentic portraits that were featured on old frescoes ${ }^{67}$ (Fig. 12). A variety of Deroko's original drawings and their visual language unmistakably suggest the atmosphere of old times.

Interestingly, in all his publications about vernacular architecture, text and drawings swapped positions. Drawings now became an essential aspect of narrative and the words only an illustration of the drawings (even when he used legends or when words described the details). The aesthetic appearance of his publications was obviously of great importance for Deroko. It seems that he supervised the printing process of his books, taking care of print style, photography, drawings, and book covers: everything that influenced the graphic appearance of his books. ${ }^{68}$ 
THEORETICAL IDEAS IN ARCHITECTURE:

CONSTANCY AND CHANGE

... great works of art 7 ive far beyond their own time ...

Deroko's approach to architectural history, heritage and design was forged during his wanderings in the wilderness of Serbia shared with his friend Petrović. Petrović was inspired by ancient Slavic mythology, and his romantic visions of the history influenced Deroko, as did the avant-garde Paris of the twentieth century. As a result, from Deroko's writings, certain specific theoretical ideas that seem to be located between tradition and modernity and that embrace both - constancy and change in architecture, can be deduced:

The Ideas of Progress and Cultural continuity with Universal values. Deroko strongly believes in approaching architecture with ethical values, appreciating and welcoming even the most extreme attempt in the arts in general if it is "sincere" and "honest". Even when such an approach is ephemeral, it always helps to clarify something and leads to some "progress". However, early in his writings, Deroko immediately also raises the question of whether art needs progress at all, confirming his rejection of any such need. Instead of the pursuit of progress in architecture, he believes there are simply different means of expression and different values. ${ }^{69}$

Deroko further discusses the question of whether architecture and urbanism are art at all. He believes that there is an architecture that can be art since there are examples from prehistory onwards when architecture was not only utilitarian. However, there is also architecture that simply cannot stand as art alone, he claims. Many practical things can be aesthetically appealing, but their function is their core value. This refers especially to a house which is primarily a person's shelter and should be as comfortable as possible. Deroko believes that such a house can hardly be an artistic creation as well. He saw vernacular architecture as an archetype of functionality resulting from the real conditions of a given place:

The shape of the building is only a pure function of the building material of an area concerned, the climatic conditions and the practical needs of a man; ... this give shapes of different kind ... and finally, it crystallizes one, not sought after by the aesthetics created by itself ... of course that the taste of the unnamed master builders and their affection for various decorations, play a role, and this taste is in function of life circumstances and local characteristics. Hence, vernacular architecture is an expression of the creative capacities of particular region, and a mirror of its artistic concepts. ${ }^{70}$ 
He believed that decisions about building must be determined by these natural conditions. ${ }^{71}$ Deroko thinks that the role of an architect is to provide a man with 'at least some quiet corner in the midst of the general bustle of streets, squares, and transport nodes'. ${ }^{72}$ Having shown again his belief in freedom in art and his understanding of modern art, he nevertheless reminds us that in creations of architecture and urbanism common/ordinary people must live. Deroko always had in mind the relationship between architecture and the ordinary man for whom it is actually created. With a slogan 'Freedom is great, but the risk is big! ${ }^{73}$ it seems that he rejects the modernists' exclusive pursuit of constant progress in architecture, warning his younger colleagues against it, although modestly pointing out that he does not want to judge or criticise. By constantly drawing attention to the modesty and dignity of a monument, Deroko compares and even equates architectural features and human personal characteristics. ${ }^{74}$ The principles of functionality, stability and timelessness associated with human existence are ever present for Deroko. He often reiterates that these universal principles of architecture are in accordance with the fundamental objectives of any significant human creation. In every major culture, they were selected as means and the guarantor of social relations, peace and stability - and are recognisable manifestations of common moral world as well.

The Ideas of "Good taste" and Monumentality. Deroko considers erecting a monument as both easy and difficult, because it is apparent recognition and a reminder of a worthy man, or a famous event. He pays due respect to the notion of monumentality in architectural history. He considers it an aesthetic criterion that can be provided by two basic conditions: first an imposing exterior appearance, achieved by bold modelling of simple and unbroken masses; and the second - a unique interior space, formed by a harmonious, spacious, attractive and well-lit cavity. ${ }^{75}$ However, he believes that monumentality is not in size, as:

The size can even be dangerous because it imposes itself too much, and so it can point out to the imperfections if they exist ... taste and measure should prevail ... that's why, even when it seems easy to set up the basic concepts, it is simple and complex equally. ${ }^{76}$

Apparently, Deroko advocates that good taste and modesty, rather than fashion, should always prevail in architecture. His recipe for good architecture would follow the scheme: successful idea - which suits the purpose/fits the function - expressed with the "right measure" and "good taste", always respecting the logic of nature and its laws. 


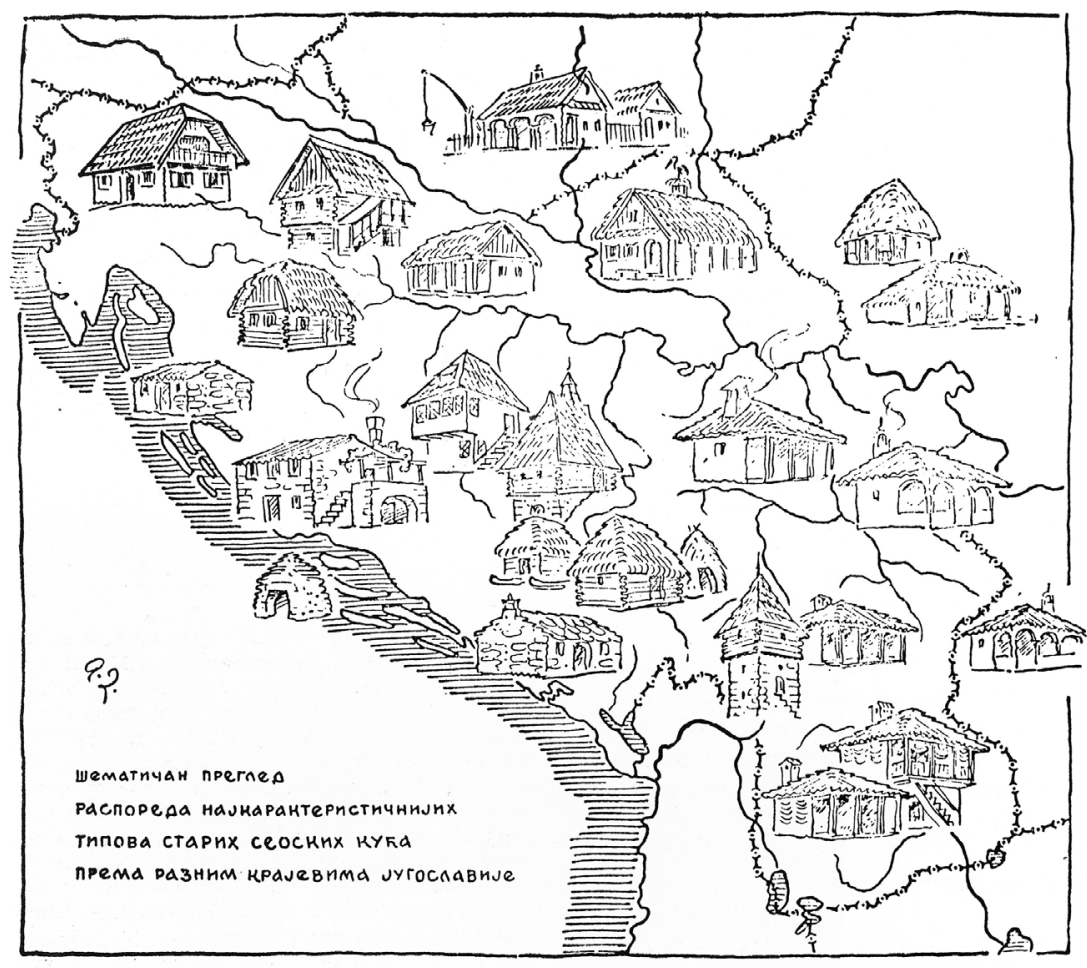

Fig. 13. Deroko's linear drawing - cartographic overview of vernacular buildings in various parts of former Yugoslavia (Source: Jovanović, Z. Aleksandar Deroko. Beograd: RZZZSK, 1991, 34.) 
The Ideas of "Spirit" and "Inspiration - not an Imitation". Deroko believed in learning from the history of architecture, often stressing that heritage deserves respect. In his writings, possibly unintentionally, but still relatively often, Deroko enters into a discussion about the Zeitgeist. He advocates a position that:

Works of art are unavoidably related to the time in which they appear and develop. As such, they are inevitably expression of their environment and the relevant time. A monument however, always tends to last long, possibly eternally, so it must not be tied only to the taste of ephemeral current fashion. As a result, great works of art live far beyond their own time, and can stay modern at all times. ${ }^{77}$

It seems that Deroko modestly criticizes modernism for its claim of appropriate response to contemporary culture and the rejection of everything else as a product of a different historical context.

He occasionally mentions the word "spirit" in a positive sense in his writings, presumably believing in a spiritual continuum between different historical periods because this has always been essential for vigour and inventiveness in architecture. Observations on the mutual influence of distant places and transfer of architectural elements are unavoidable in Deroko's architectural history and he often uses analogy as a method (Fig. 13). Constantly drawing attention to architectural elements travelling through space and time ${ }^{78}$, he presentes the mutual influence of building activity between nations and traditions as something natural. He notes that the many architectural forms/shapes transferred to medieval Serbia were not simply imposed by foreign master builders, and that the 'borrowed and foreign' identity of such forms/shapes did not long persist. Rather the old Serbian builders combined, reinterpreted and treated adopted elements in their own particular way. Regardless of forms/shapes and individual elements, the dominant/strongest characteristic of art is "its spirit". Deroko pays attention to the fact that what was built in medieval Serbia, while not completely original in style, still makes Serbian architectural monuments recognisable, and distinct from other sacral architectural monuments in this part of the world, sometimes even exceeding them..$^{79}$ This leads us to the conclusion that he was advocating "spirit" in architecture only in the sense of spirituality that exists regardless of its specific time. ${ }^{80}$

That past can be recaptured only in "spirit" since it unmistakably carries the patina of antiquity and connects it with the present. ${ }^{81}$ However, at the same time, from Deroko's very first texts it is obvious that he was against the idea of mimicking historical buildings in new ones: 
Less and less is being built today in the way it was built for hundreds of years. Nothing can help here, nor should it be artificially and vigorously corrected because, one time lives under one circumstances and its building style is a spontaneous expression of only those occasions and that time. A different time, whether wanting to or not, creates under different circumstances, its own, at least somewhat different style. ... There were attempts to make up and officially impose a style that would represent the epoch in question. The results did not last long. ${ }^{82}$

Similar attitudes showing that Deroko does not advocate literal imitation of the past with new architecture can be found in his numerous articles ${ }^{83} \mathrm{He}$ calls on architects to appreciate the past, underlining that 'cultural heritage is to be kept up with' and should serve as an inspiration, a refreshment and encouragement to a poetic idea with its naivety and deep sensibility, but not as a direct source for imitation.

\section{CODA}

Deroko raises many questions and admits that he does not know answers, showing that the architectural profession has to deal with numerous, difficult, and at times insoluble problems ${ }^{84}$ - a prime example of his not offering a definite solution with his architectural theory, if we can call it a theory at all. However, he certainly belongs to a group of architectural historians who, with his warm and intimate writing style, researched and presented the way architectural works were designed and built throughout history. His approach to architectural history was based on the supposition that it is possible to accumulate knowledge on the elements of good design, and that there is obviously much to learn from the way in which architectural works were shaped throughout the past. He was interested in discovering the design methods of anonymous architects, and in explaining how he believed buildings of the past were designed. He sought to identify anonymous builders' approaches to basic concepts of function, space, form/shape, architectural details and the way they were modelled, and all the formal qualities of their buildings, along with their mutual influences and transpositions. In other words, Deroko in his writings predominantly studied and presented formal properties of architecture and tried to outline an intellectual framework for understanding how a particular building, medieval city, or vernacular house was built.

Although he does believe in a creative "spirit" in architecture of the past and present, it appears that Deroko does not in general trust the Modernist ideas of "the spirit of the time". Similarly, he advocates the preservation of actual 
historical buildings and medieval towns, but he rejects the idea of copying them in new buildings. He does not recognise innovation or pursuing "the idea of progress" in architecture as a virtue. Instead, he is interested in the pursuit of what is universal - valid for all times and, at the same time particular and specific to their own local region. In his writings, Deroko supports traditional principles of architecture, primarily related to the functionality and stability of buildings as an absolute requirement for good architecture. Although he deeply believes in constant and natural transformation in architecture, its elements and details since time immemorial, he also insists on the lasting quality of architecture that goes beyond the lifetime of its builders and believes that anonymous builders in vernacular buildings developed both - universal values and local styles. For Deroko it is important that architecture successfully meets the demands of function and construction in different political systems, cultures and geographical areas, standing the test of time as a "canon" that plays a real role in any culture and sets standards of excellence.

So, in all human creation, the attitude that equates the two - the search for authenticity and awareness of one's roots - characterises Deroko's thoughts. Only seemingly antagonistic, in his theoretical ideas there is actually no opposition; rather, there is a delicate but decisive balance between tradition and modernity, universality and regionalism, and constancy and change. The same as with Petrović, Deroko's romantic visions about the origin on one side, and his rational and methodical approach to the surveying of heritage and to writing of both - his early texts and later architectural textbooks on the other, resulted in very novel, unique and unsurpassed theoretical ideas in architecture of the early twentieth century. Although not acknowledged in his own country, his ideas are still part of the mainstream architectural discourse, and are discussed and debated internationally. 

presented in this paper, and for the original stimulus to write about professor Aleksandar Deroko. My gratitude also belongs to Karen Wise and Iris Arsić, whose selfless help with the written English of the paper was decisive for its final form. Misao X (1922): 1,673-1,686. (Beograd: Republički zavod za zaštitu spomenika kulture, 1991), 101-109.

The very first textbook was Djurdje Bošković, Srednjovekovna umetnost u Srbiji i Makedoniji (crkvena arhitektura i skulptura) (Beograd: Jugoslovenska knjiga, 1948). However, Deroko's textbooks were the most popular and pedagogically very appropriate; more about this later in the text.

Aleksandar Deroko, A ondak je letijo jeroplan nad Beogradom (Beograd: Narodna knjiga, 1983; Beograd: Dereta, 2013), 9. 
Jovan Deretić, "Kratka istorija srpske književnosti," in Rastko Petrović - Elektronska Biblioteka, edited by Dejan Ajdačić.

Zdravko Petrović, Kreativni haos Burleske gospodina Peruna boga groma: o konstruisanoj dekonstrukciji avangardnog romana Rastka Petrovića (Beograd: Službeni glasnik, 2011); Predrag Petrović, Avantgardni roman bez romana; Poetika kratkog romana srpske avant-garde (Beograd: Institut za knjizevnost i umetnost, 2008).

Zoran Mišić, "Rastko Petrović", in Rastko Petrović - Elektronska Biblioteka, edited by Dejan Ajdačić.

Deroko, A ondak je letijo jeroplan nad Beogradom, 127-129.

Deroko, A ondak je letijo jeroplan, 153.

Deroko, A ondak je letijo, 154-156.

Aleksandar Deroko, Mangupluci oko Kalimegdana (Beograd: Dereta, 2014), 86-87.

Deroko, Mangupluci, 87.

Deroko, A ondak je letijo jeroplan, 151-157; Deroko even compares his drawings with his literature by saying that 'many Rastko's verses and prose are pure visual images of distinctive colour'.

Deroko, A ondak je letijo, 158.

Deroko, A ondak je letijo, 160-72.

Radovan Popović (ed), Deroko i drugi o njemu (Beograd: Turistička štampa, 1984), 41; It was 1927, in Picasso's studio; he told him to watch out on his way out that a doorman does not see it, because at that time each Picasso's sketch still belonged to gallerist Rosenberg under contract.

Deroko, A ondak je letijo, 159.

Deroko, Mangupluci, 182; Deroko, A ondak je letijo, 125, 152-157.

Deroko, A ondak je letijo, 159.

Interview with Moma Dimić, Savremenik 6 (1985); in: Deroko, Mangupluci, 231-263.

On Deroko's role in the history of heritage protection in Serbia and his involvement in the field of the architectural heritage conservation and preservation see: Jovanović, Aleksandar Deroko, 41-50; For the history of heritage protection in Serbia in general see: Milan Popadić, "The Preservation and Presentation of Medieval Heritage in Serbia in the $19^{\text {th }}$ and $20^{\text {th }}$ Centuries," Imagining the Past. The Reception of the Middle Ages in Serbian Art from the $18^{\text {th }}$ to the $21^{\text {st }}$ Century. Byzantine Heritage and Serbian Art III (Belgrade, 2016), 211-218; Miladin Lukić, "The Functioning of the Institutes for Protection of Cultural Monuments in Serbia," Condition of the Cultural and Natural Heritage in the Balkan Region, Proceedings, (Kladovo, 2006), 341-356.

Aleksandar Deroko, "Kruna i blago cara Dušana," [The Crown and the Treasure of Emperor Dušan] Vreme (6 October 1932; 14 September 1932); Deroko, Mangupluci, 101.

Aleksandar Deroko, "Povodom jednog S.O.S. apela još od pre dvadeset godina," [On the occasion of one S.O.S. appeal from twenty years ago] Misao XII (1923): 838-842; "O zaštiti starina," [About Protection of Antiquities] Srpski književni glasnik XXXIII (1933): 373-380, 449-457, 533-544; "Restauracija manastira Sedmovratne Žiče privodi se kraju," [Restoration of the Sedmovratna Žiča Monastery is Coming to an End] Vreme (19 August 1932); Deroko, Mangupluci, 94, 104.

Deroko, Mangupluci, 101.

Deroko, Mangupluci, 95, 102; To reach the Sopoćani monastery, Deroko and Popović used a carriage to the village Doljani, but further on they had to jump over the wooden fences between yards belonging to Arnaut (Ottoman term for an Albanian) and plum yards, to the disapproval of the residents. 
Deroko, Mangupluci, 103; Deroko writes: “... to "rescue" and transfer the entire floor mosaic in Stobi, Strala painter dug out the ground beneath it and put under the wheels of trollies, and managed to pull everything, together with the base, as a single block'.

Deroko, "Povodom jednog S.O.S. apela još od pre dvadeset godina"; Deroko, "Kruna i blago cara Dušana"; Aleksandar Deroko, Srednjevekovni gradovi u Srbiji, Makedoniji i Crnoj Gori (Beograd: Prosveta, 1950), 7; Deroko, Mangupluci, 95, 97, 99, 100.

Deroko, Mangupluci, 103-106. With the example of Lepenski vir, Deroko challenges authenticity because the in situ original was gone.

Deroko, "Tri manastira srednjevekovnog Rasa"; Deroko, "Povodom jednog S.O.S. apela još od pre dvadeset godina"; Deroko, "Izdanja narodnog muzeja u Beogradu," Srpski književni glasnik XXXII (1931): 67-69; Deroko, "Restauracija manastira Sedmovratne Žiče privodi se kraju”; Deroko, "Na putu za kolevku drevne države Nemanjića," [On the Way to the Cradle of the Ancient State of Nemanjići] Vreme (20 July 1933); Deroko, Mangupluci, 103-104, 93-94.

Deroko, Srednjevekovni gradovi u Srbiji, Crnoj Gori i Makedoniji, 206; 'This would neither be an expensive nor a big job, because we have very few relatively good preserved medieval cities. Medieval cities located in the urban areas may be converted into parks after cleaning and stabilising, but nothing new should be built there. In that way, those cities would become aesthetically pleasing and attractive parts of the landscape, suitable for contemporary times, and not just uninteresting archaeological and museum objects. Even those cities of which only foundations are preserved, should be dug out, unblocked, made safe, and protected from further re-burying and overgrowing weeds. All of them should be entrusted to supervision by local national authorities to save them from further demolition. Only by these means can those old monuments be preserved, and become documents and testimonies that will bind us to the ancient past and enable us to know it better.' Similar opinion can be found in numerous articles Deroko wrote in the 1930s.

See note 32 and Deroko, Mangupluci, 104-106.

Aleksandar Deroko, Monumentalna i dekorativna arhitektura u srednjevekovnoj Srbiji. Monumental and Decorative Architecture in Medieval Serbia (Belgrade: Serbian Academy of Arts and Sciences, 1953; second edition 1962); later, Narodna arhitektura - knjiga I, Spomenici arhitekture IX-XVIII veka u Jugoslaviji (National Architecture - Book I, Architectural Monuments of IX-XVIII century in Yugoslavia), Beograd: Građevinska knjiga, 1964; luxury edition in French, Avec Les Maitres d' Autrefois (Monastères médiévaux en Serbie, Macédoine, Monténégro), (Beograd: Turistička štampa 1967).

See: Aleksandar Deroko, Starinar I (1950): 280 (Review of the book: Djurdje Bošković, Srednjovekovna umetnost u Srbiji i Makedoniji (crkvena arhitektura i skulptura), Beograd, 1948). See also: Miloje Vasić, Žiča i Lazarica (Beograd: Izdavačka knjizarnica Gece Kona, 1928), VIIVIII; Foreword from November 1927 that mentions Deroko between other names who 'actively, gladly and with self-sacrifice participated in the preparation of this work, and often in the discussion gave an incentive for new observations and new thought ... The front cover and book dedication are Mr. Aleksandar Deroko, an architect.

Jovanović, Aleksandar Deroko, 32, cites: M. Rogic, 'Knjiga o arhitekturi u Jugoslaviji od IX-XVIII veka (prikaz knjige S. Nenadovića)', Beograd: Sveske društva istoričara 9-10 (1980): 44-45, as the source that considered Deroko's books as not having the breadth of Mango or Krautheimer on Byzantine art.

Aleksandar Deroko, Srednjevekovni gradovi u Srbiji, Crnoj Gori i Makedoniji (Beograd: Prosveta, 1950). 5), (Beograd, 1951). 
Deroko, Srednjevekovni gradovi u Srbiji, Crnoj Gori i Makedoniji, 7. For cities that were not already written about, the data were taken from relevant publications, and at the same time were revised. Deroko confirmed that he used the existing literature of the cities, although it was not cited everywhere in the text, in order to prevent it being cluttered with remarks and less clear as a result (bibliography is attached to the end of the book).

Jovan Nešković, "In memoriam, A. Deroko," Glasnik društva konzervatora Srbije 13 (1989): 284-287; Deroko's work on vernacular architecture compared with the study of Serbian medieval monuments that did have a certain tradition that could be followed.

Aleksandar Deroko, Narodna arhitektura II, Folklorna arhitektura u Jugoslaviji (Beograd: Građevinska knjiga, 1964; Beograd: Naučna knjiga, 1974).

Aleksandar Deroko, Narodno Neimarstvo II, Stara varoška kuća (Beograd: SANU, 1968).

Nešković, "In memoriam, A. Deroko,” 284-287.

Aleksandar Deroko, Narodno neimarstvo I and II (Vernacular Architecture I and II), (Institut za narodnu umetnost Beogradskog Univerziteta, 1939, 1940).

Deroko confirms that old Serbian art has long been highly regarded, but also points at an absence of a-comprehensive general publication after Millet's book was published in 1919.

Deroko, Monumentalna i dekorativna, 6.

Deroko, Narodna arhitektura I, 25-26; Monumentalna i dekorativna, 23: 'We can notice immediately that the most important are four groups (out of five) in the architectural sense, but that the third and the fourth make one narrower stylistic entity as well, so the focus is finally on the three stylistic groups.'

Deroko, Monumentalna i dekorativna, 27: 'We have adopted this kind of grouping for easier orientation when observing the basic characteristics of the development of all architecture in medieval Serbia. Their basic forms/shapes have evolved into an original/genuine type, while the exterior treatment belongs, more or less, to Romanesque style.'

Deroko, Monumentalna i dekorativna, 98; Deroko, Narodna arhitektura I, Spomenici arhitekture IX-XVIII veka u Jugoslaviji, 90.

Deroko, Narodna arhitektura I, Spomenici arhitekture IX-XVIII veka u Jugoslaviji, 264.

Deroko, Srednjevekovni gradovi u Srbiji, 231.

Deroko, Srednjevekovni gradovi u Srbiji, Crnoj Gori i Makedoniji, 5.

Deroko, Srednjevekovni gradovi u Srbiji, 233.

Deroko, Srednjevekovni gradovi u Srbiji, Crnoj Gori i Makedoniji, 6.

Deroko, Narodno Neimarstvo II, Stara varoška kuća, 271-272.

Deroko, Narodna arhitektura II, Folklorna arhitektura u Jugoslaviji, 3.

This was a permanent concern for Deroko which he expressed in numerous early articles, starting from "Tri manastira srednjevekovnog Rasa" in 1922.

Deroko, Narodno Neimarstvo II, Stara varoška kuća, 271-272; However, he emphasizes that it could never be definite because it was always replaced by newer materials, mostly due to the deterioration of old houses.

Deroko, Narodno Neimarstvo II.

Aleksandar Deroko, Arhitektura starog veka (Beograd: Univerzitet u Beogradu, Naučna knjiga), 1962. 
Deroko, Narodna arhitektura I, Spomenici arhitekture IX-XVIII veka u Jugoslaviji, 34.

Deroko, Srednjevekovni gradovi u Srbiji, Crnoj Gori i Makedoniji, 7.

Aleksandar Deroko, "Prikaz knjige Narodno neimarstvo," Glasnik SANU XIX (1969): 63-65; Deroko i drugi o njemu, 47.

Deroko, Mangupluci, 156-157.

Deroko, Narodno Neimarstvo II, 1940, I.

Aleksandar Deroko, "Estetika kuće u polju," [Aesthetics of the Country House] Umetnički pregled 1 (1938): 142-143; Deroko, "O estetskom kriterijumu u starom našem neimarstvu," [On the aesthetic criterion in our old architecture] XX vek (1938): 13-17; Deroko, "Folklor u arhitekturi kod nas se više ne obnavlja," [Vernacular Architecture is not Restored Anymore] Telegram (21 September 1939): 7; Deroko, "Naša folklorna arhitektura," [Our Vernacular Architecture] Umetnički pregled 3 (1940): 78-79; Deroko, Mangupluci, 157; Deroko is quite reserved towards modernism that uses certain chosen-in-advance elements independent of natural conditions: 'Many architects tried to compromise, to reconcile facts (Loose, Le Corbusier, Niemeyer and Wright, and many others who followed them). When it comes to utilitarian architecture and urbanism, it is difficult to reach a compromise ... townhouses are primarily for housing, trade, for supplies, for administration, etc. Streets are primarily for the circulation of people between all this'.

Deroko, Mangupluci, 158.

Deroko, Mangupluci, 163. Let them be brave, as they feel, and create the "new" and the "modern", but they risk a lot, because what they set in front of us, in concrete and stone, and we tripped over it ... does not belong to them only.

Deroko, Mangupluci, 164. Monument in Lunjevački gaj dedicated to the memory of the peasant, in "a modest and dignified manner to pay respect and recognise a humble and dignified man.

Deroko, "Prvi monumentalni hram Beograda," [The First Monumental Temple of Belgrade] Srpski književni glasnik XXXVII (1932): 630-631; Deroko, "Hram Svetoga Save," Vreme (6 January 1933); Deroko, Narodna arhitektura I, Spomenici arhitekture IX-XVIII veka u Jugoslaviji, 32.

Aleksandar Deroko, Politika (4 August 1974); "Kuće i drugi neimarski dani," Gradina 8-9 (1981); A ondak je letijo jeroplan, 278, 287; Mangupluci, 162; Narodno Neimarstvo II, 1940, I.

Deroko, Mangupluci, 162.

Deroko, "Stare naše tvrdjave," [Our Old Fortresses] Umetnički pregled 2 (1937): 39-41; Deroko, "Istok, zapad i mi," [The East, the West and Us] Umetnički pregled 13 (1938): 396-398; Deroko, "O estetskom kriterijumu u starom našem neimarstvu”; Deroko, Monumentalna i dekorativna, 22, 229; Deroko, Narodna arhitektura I, Spomenici arhitekture IX-XVIII veka u Jugoslaviji, 70.

See the same articles as above and Deroko, Monumentalna, 15.

Deroko, Mangupluci, 155.

Some of Deroko's own built projects often incorporate old architectural elements into a new design. For example, the House on the Topčider Hill, or the Ossuary for Sarajevo assassinators, Deroko himself considers it a good example, in: Aleksandar Deroko, Politika (4 August 1974); "Kuće i drugi neimarski dani," Gradina 8-9 (1981); Deroko, A ondak je letijo, 289; Deroko i drugi o njemu, 47.

Deroko, "Naš nacionalni stil u arhitekturi," [Our National Style in Architecture] Vreme (6 January 1941).

Deroko, "Izložba naših vizantiskih umetničkih dela," [The Exhibition of our Byzantine art works] Politika (12 April 1927); Deroko, "Stara naša umetnost i savremeno stvaranje," Vreme (1 May 1932); "Naše Starine," [Our Antiques] Interview with Miloš Crnjanski, Vreme (15 April 1933); Deroko, "Folklor u arhitekturi kod nas više se ne obnavlja". 
Ajdačić, Dejan (ed). Rastko Petrović - Elektronska Biblioteka, 2003; https://www.rastko.rs/ knjizevnost/umetnicka/rpetrovic/index_c.html

Bogdanović, Bogdan. Aleksandar Deroko. Umetnici akademici 1968-1978. Beograd: SANU, 1981

Bogunović, Slobodan. Arhitektonska encikopedija Beograda, II. Beograd: Beogradska knjiga, 2005, $750-757$.

Bošković, Djurdje. Srednjovekovna umetnost u Srbiji i Makedoniji (crkvena arhitektura i skulptura), Beograd: Jugoslovenska knjiga, 1948.

Deroko, Aleksandar. “Djurdje Bošković, Srednjovekovna umetnost u Srbiji i Makedoniji.” Starinar I (1950): 280 .

Deroko, Aleksandar. "Estetika kuće u polju." (“Aesthetics of the Country House”) Umetnički pregled 1 (1938): 142-143.

Deroko, Aleksandar. "Folklor u arhitekturi kod nas se više ne obnavlja." ("Vernacular Architecture is not Restored Anymore") Telegram (21 September 1939): 7.

Deroko, Aleksandar. "Hram Svetoga Save.” Vreme (6 January 1933).

Deroko, Aleksandar. "Istok, zapad i mi." ("The East, the West and Us") Umetnički pregled 13 (1938): 396-398.

Deroko, Aleksandar. "Izdanja narodnog muzeja u Beogradu." Srpski književni glasnik XXXII (1931): 67-69.

Deroko, Aleksandar. "Izložba naših vizantiskih umetničkih dela." ("The Exhibition of our Byzantine art works") Politika (12 April 1927).

Deroko, Aleksandar. "Kruna i blago cara Dušana." ("The Crown and the Treasure of Emperor Dušan") Vreme (6 October 1932; 14 September 1932).

Deroko, Aleksandar. "Na putu za kolevku drevne države Nemanjića." ("On the Way to the Cradle of the Ancient State of Nemanjići") Vreme (20 July 1933).

Deroko, Aleksandar. "Naš nacionalni stil u arhitekturi." ("Our National Style in Architecture") Vreme (6 January 1941).

Deroko, Aleksandar. "Naša folklorna arhitektura." (“Our Vernacular Architecture”) Umetnički pregled 3 (1940): 78-79.

Deroko, Aleksandar. "Naše starine.” (“Our Antiques”) Intervju sa Miloš Crnjanski, Vreme (15 April 1933).

Deroko, Aleksandar. "O estetskom kriterijumu u starom našem neimarstvu." ("On the aesthetic criterion in our old architecture") XX vek (1938): 13-17.

Deroko, Aleksandar. "O zaštiti starina.” (“About Protection of Antiquities”) Srpski književni glasnik XXXIII (1933): 373-380, 449-457, 533-544.

Deroko, Aleksandar. "Povodom jednog S.O.S. apela još od pre dvadeset godina." ("On the occasion of one S.O.S. appeal from twenty years ago") Misao XII (1923): 838-842.

Deroko, Aleksandar. "Pre tolikih stoleća." ("Many Centuries Ago") Vreme (6-8 January 1926).

Deroko, Aleksandar. "Prvi dani Jugoslovenske umetnosti." ("The first days of Yugoslav art") Vreme (6 January 1931)

Deroko, Aleksandar. "Prvi monumentalni hram Beograda." ("The First Monumental Temple of Belgrade”) Srpski književni glasnik XXXVII (1932): 630-631.

Deroko, Aleksandar. "Restauracija manastira Sedmovratne Žiče privodi se kraju." ("Restoration of the Sedmovratna Žiča Monastery is Coming to an End") Vreme (19 August 1932).

Deroko, Aleksandar. "Rušenje Banove zadužbine u Gradcu zato što nije u 'stilu' pravoslavnih crkava." Vreme (2 October 1926). 
Deroko, Aleksandar. "Stara naša umetnost i savremeno stvaranje." (“Our Old Art and Modern Creation") Vreme (1 May 1932).

Deroko, Aleksandar. "Stare naše tvrdjave.” (“Our Old Fortresses”) Umetnički pregled 2 (1937): $39-41$.

Deroko, Aleksandar. "Tri manastira srednjevekovnog Rasa." ("Three Monasteries of Medieval Ras”) Misao X (1922): 1673-1686.

Deroko, Aleksandar. "U mrtvim gradovima Duklje." (“In the Dead Towns of Duklja”) Vreme (28 August 1929).

Deroko, Aleksandar. A ondak je letijo jeroplan nad Beogradom, Beograd: Narodna knjiga, 1983; Beograd: Dereta, 2013.

Deroko, Aleksandar. Arhitektura starog veka, Beograd: Univerzitet u Beogradu, Naučna knjiga, 1962.

Deroko, Aleksandar. Mangupluci oko Kalimegdana, Beograd, 1987; Dereta, 2014.

Deroko, Aleksandar. Monumentalna i dekorativna arhitektura u srednjevekovnoj Srbiji. Monumental and Decorative Architecture in Medieval Serbia, Belgrade: Serbian Academy of Arts and Sciences, 1953; second edition 1962.

Deroko, Aleksandar. Narodna arhitektura - knjiga I, Spomenici arhitekture IX - XVIII veka u Jugoslaviji (National Architecture - Book I, Architectural Monuments of IX - XVIII century in Yugoslavia), Beograd: Građevinska knjiga, 1964.

Deroko, Aleksandar. Narodna arhitektura II, Folklorna arhitektura u Jugoslaviji, Beograd: Građevinska knjiga, 1964; Beograd: Naučna knjiga, 1974.

Deroko, Aleksandar. Narodno neimarstvo I, Stara seoska kuća, Beograd: SANU, 1968.

Deroko, Aleksandar. Narodno Neimarstvo II, Stara varoška kuća, Beograd: SANU, 1968.

Deroko, Aleksandar. Narodno neimarstvo I and II (Vernacular Architecture I and II), Institut za narodnu umetnost Beogradskog Univerziteta, 1939. 1940.

Deroko, Aleksandar. Srednjovekovni gradovi na Dunavu, Beograd: Turistička štampa, 1964.

Deroko, Aleksandar. Srednjevekovni gradovi u Srbiji, Makedoniji i Crnoj Gori, Beograd: Prosveta, 1950.

Ilijevski, Aleksandra. "Status i značaj gradjevina Aleksandra Deroka izvedenih u starom jezgru Beograda." In Stara gradska jezgra i istorijske urbane celine: problem i mogućnosti očuvanja $i$ upravljanja, 327-341. Beograd: ZZZSKGB, 2013.

Jovanović, Zoran M. Aleksandar Deroko. Beograd: Republički zavod za zaštitu spomenika kulture, 1991.

Jovanović, Miodrag. Srpsko crkveno graditeljstvo i slikarstvo novijeg doba. Beograd - Kragujevac: Društvo istoričara umetnosti Srbije, "Kalenić", 1987.

Kadijević, Aleksandar. "Evokacije i parafraze Vizantijskog graditeljstva u Srpskoj arhitekturi od 1918. do 1941. godine.” Niš i Vizantija II (2004): 379-392.

Legende Beogradskog Univerziteta: Aleksandar Deroko 1894-1988. Katalog izlozbe. Beograd: UBSM, 2008.

Lukić, Miladin. "The Functioning of the Institutes for Protection of Cultural Monuments in Serbia." In Condition of the Cultural and Natural Heritage in the Balkan Region, 2006, ed. Mila Popović Zivančević, 341-356. Serbia: Kladovo, 2006.

Manević, Zoran. Leksikon neimara, Beograd: Gradjevinska knjiga, 2008.

Millet, Gabriel. L'ancien art Serbe: Les églises, Paris: E. de Boccard, 1919.

Nešković, Jovan. "In memoriam, A. Deroko.” Glasnik drustva konzervatora Srbije 13 (1989): 284287. 
Petrović, Predrag. Avantgardni roman bez romana; Poetika kratkog romana srpske avant-garde. Beograd: Institut za knjizevnost i umetnost, 2008.

Petrović, Zdravko. Kreativni haos Burleske gospodina Peruna boga groma: o konstruisanoj dekonstrukciji avangardnog romana Rastka Petrovića. Beograd: Službeni glasnik, 2011.

Popadić, Milan. "The Preservation and Presentation of Medieval Heritage in Serbia in the $19^{\text {th and }}$ ${ }^{20 \text { th }}$ Centuries." in Imagining the Past. The Reception of the Middle Ages in Serbian Art from the 18 th to the 21 st Century, ed. Lidija Merenik, Vladimir Simic, Igor Borozan (Belgrade: Byzantine Heritage and Serbian Art III, 2016), 211-218.

Popović, Radovan (ed). Deroko i drugi o njemu. Beograd: Turistička štampa, 1984.

Srpska arhitektura 1900-1970. Jugoslovenska umetnost XX veka. Beograd: Muzej savremene umetnosti, 1972.

Vasić, Miloje. Žiča i Lazarica. Studije iz Srpske umetnosti srednjeg veka. Beograd: Izdavačka knjizarnica Gece Kona, 1928. 